\title{
EFFECT OF RISK ANALYSIS ON PERFORMANCE OF LARGE CONSTRUCTION PROJECTS IN KUWAIT
}

\author{
Rashid Aldaiyat \\ MPW, Maintenance of road and networks department, Riqqa, Ahmadi, Kuwait; \\ aldaiyat1988@gmail.com
}

\begin{abstract}
Since construction projects are usually associated with high range of risks, risk analysis is an essential part within the decision-making processes in this industry. This study aims at finding the effect of appropriate risk analysis on enhancing the performance of the large construction projects in Kuwait. Through this correlational descriptive and qualitative study; firstly, a questionnaire was used to collect the main data where it was distributed on a sample of (150) engineers working in the large construction projects in Kuwait. Moreover, an interview was conducted with (15) project managers in the large construction projects in Kuwait. The results of the questionnaire showed that risks analysis aspects are highly implemented in Kuwait and that the performance indices for the construction projects are high. Moreover, it was found that there is a statistically significant positive effect of risk analysis on the performance of the large construction projects in Kuwait. The results showed that there were statistically significant differences in the effect of risk analysis on the performance of the construction projects attributed to the project type in favor of the private projects. Finally, the results of the interview showed that client satisfaction and maintain resources are the main effects of appropriate risk analysis tools, where project managers assured that re-allocating risks and changing roles are the main mechanisms to lessen the risks within the large construction projects in Kuwait.
\end{abstract}

\section{KEYWORDS}

Risk analysis, Construction projects, Project performance, Kuwait

\section{JEL CLASSIFICATION}

L740, D810, H430

\section{INTRODUCTION}

Construction projects are usually complex and full of uncertainties [1]. Such uncertainties are risks that can have possibly harmful consequences on the project [1, 2]. Risks can affect the accomplishment of the project objectives, which in turn will result in poor project performance [3]. That is why risk analysis is considered now as a fundamental project management feature, especially in the construction industry, that aims to effectively deal with unexpected events and uncertainties for achieving the project success $[4,5]$.

Risk analysis procedure includes the prospective risks critical evaluation, risks classification based on their significance, and the capability of the management to choose the main ones [6, 7]. Risk analysis is a multi-tasking process in the risk management since it includes assessing the likelihood of the risks and their impacts on the objectives of the project $[8,9]$. The objective of risk analysis within construction projects is evaluating the possible risks by classifying the risk events according to their importance, chances of happening, and the size of each risk [10]. In other words, risk analysis is the intermediate process between risk identifying and risk management [11]. 


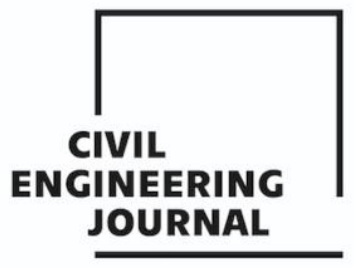

Article no. 58

THE CIVIL ENGINEERING JOURNAL 3-2021

The importance of risk analysis in mitigating the possible risks within construction projects have been discussed widely [4, 12-15]. However, its effects on the construction project performance are still under discussion according to the indicators that have been adopted to determine the performance [16].

Kerzner (2017) argued that risks presence within the project development can affect the project objectives, which might result in a difficult decision-making associated processes [17]. Musta (2019) confirmed that effect as he found that the risk weight affect the risk probability, which in turn affect the project objectives including quality, time and costs [18]. In this study, the effect of risk analysis on the comprehensive framework of construction project performance as proposed by Nassar (2009) with eight indicators was investigated.

\section{METHODS}

In this study, the correlational descriptive and qualitative method was followed, as it is the most appropriate approach for the subject of the study. Both the questionnaire and interview were used as the data collection tools.

\section{Population and sample}

The population of this study consisted of all the working engineers in the large construction projects in Kuwait in the time of conducting this study, besides the project managers in the same projects. As the study population number could not be attained precisely, where the statistics ${ }^{1}$ inform that $(7.5 \%)$ of the total working force in Kuwait are in the construction sector and that (10\%) of them are engineers and (1\%) are project managers. Therefore, the study sample was determined to be (150) engineers for the questionnaire part and (15) project managers for the interview part with a level of confidence of $(85 \%)$ and an error margin of $(0.05)$. The convenient sampling method was adopted until the representative study sample was achieved.

\section{Instrumentation}

Firstly, the questionnaire was adopted where the author designed it based on the review of the previous studies mainly $[19,20]$. The first draft of the questionnaire was presented to a panel of attributers specialized in project and risk management especially in the construction projects. The panel gave their comments and after making the required modifications, the second draft was prepared. In order to validate the questionnaire, it was distributed to a pilot study of (5) engineers from outside the study sample and after calculating the Cronbach Alpha coefficient, the final copy of the questionnaire was distributed on the study sample. The value of Cronbach Alpha coefficient was (0.90), indicating a good consistency of the questionnaire.

The final copy of the questionnaire consisted of two parts; the first part consisted of the sample demographics, while the second part consisted of two fields (risk analysis aspects and project performance indicators). The first field consisted of (14) items, while the second consisted of (8) items.

The interview part consisted of the main questions the questionnaire without the choices to select from to take a better perspective for the casual relationship that might exist between the main two variables of the study.

${ }^{1}$ https://www.csb.gov.kw/Pages/Statistics?ID=13\&ParentCatID=1 


\section{Statistical analysis}

The statistical analysis was conducted using the (SPSS) program where the descriptive variables including (frequencies, percentages means and standard deviation) were calculated to descriptive the study variables. Moreover, Pearson Correlation Coefficient was calculated to test the correlation between the study variables. In order to find the differences in the sample answers that might be attributed to the working setting, t-test was used. For the interview part, MAXQDA Analytics Pro 2018 software was used to analyse and code the answers of the sample under two themes; the risk analysis aspects and the indicators of the construction project performance.

\section{RESULTS}

The following sections represent the results of this study. The demographics of the study sample are listed in Table (1) below represented by frequencies and percentages, where it can be seen that the majority of the sample are males (89\%). Nearly half of the respondents $(46.6 \%)$ have an experience less than five years and most of them (76.7\%) have a bachelor degree. Most of the respondents (74\%) are working in the public sector with different job titles as showed in the table below.

Tab. 1 - Demographics of the study sample

\begin{tabular}{|c|c|c|}
\hline \multicolumn{2}{|c|}{ Variable } & $\mathrm{N}(\%)$ \\
\hline \multirow{3}{*}{ Gender } & Male & $134(89 \%)$ \\
\hline & Female & $16(11 \%)$ \\
\hline & Total & $150(100 \%)$ \\
\hline \multirow{4}{*}{ Experience } & Less than 5 years & $70(46.6 \%)$ \\
\hline & 5 to 10 years & $36(24 \%)$ \\
\hline & More than 10 years & $44(29.4 \%)$ \\
\hline & Total & $150(100 \%)$ \\
\hline \multirow{4}{*}{ Educational level } & Bachelor & $115(76.7 \%)$ \\
\hline & Masters & $26(17.3 \%)$ \\
\hline & $\mathrm{PhD}$ & $9(6 \%)$ \\
\hline & Total & $150(100 \%)$ \\
\hline \multirow{3}{*}{ Working setting } & Public sector & $39(26 \%)$ \\
\hline & Private sector & $111(74 \%)$ \\
\hline & Total & $150(100 \%)$ \\
\hline \multirow{9}{*}{ Job title } & Project Manager & $7(4.7 \%)$ \\
\hline & Assistant Project Manager & $19(12.6 \%)$ \\
\hline & Civil Engineer & $45(30 \%)$ \\
\hline & Building Inspector & $3(2 \%)$ \\
\hline & Surveyor & $2(1.3 \%)$ \\
\hline & Field Engineer & $31(20.7 \%)$ \\
\hline & Construction Engineer & $25(16.7 \%)$ \\
\hline & Planner & $18(12 \%)$ \\
\hline & Total & $150(100 \%)$ \\
\hline
\end{tabular}




\section{CIVIL}

ENGINEERING

The results of Table (2) below shows that the level of practicing the risk analysis aspects within the large construction projects in Kuwait was high with a mean of (3.71) and a standard deviation of (1.26). The item "Risk allocation analysis was performed" came first with a mean of (4.30) and a standard deviation of (1.70) in a high level. On the other hand, the item "The communication processes were e-evaluated and enhanced" came last with a mean of (2.70) and a standard deviation of (1.40) in a medium level.

Tab. 2 - Study sample answers for the items of the risk analysis aspects

\begin{tabular}{|c|c|c|c|c|c|}
\hline No. & Item & Mean & SD & Rank & Level \\
\hline 1 & Computer simulations and software were used & 3.75 & 1.50 & 9 & High \\
\hline 2 & $\begin{array}{l}\text { The financial impacts of the different risks were } \\
\text { identified and compared }\end{array}$ & 3.20 & 1.55 & 12 & Medium \\
\hline 3 & $\begin{array}{c}\text { The organizational impacts of the different risks were } \\
\text { identified and compared }\end{array}$ & 4.00 & 1.04 & 6 & High \\
\hline 4 & $\begin{array}{c}\text { The gaps in the current safety procedures were } \\
\text { identified }\end{array}$ & 4.23 & 1.22 & 2 & High \\
\hline 5 & $\begin{array}{l}\text { The decision-making processes were e-evaluated } \\
\text { and enhanced }\end{array}$ & 3.90 & 1.06 & 8 & High \\
\hline 6 & $\begin{array}{l}\text { The communication processes were e-evaluated and } \\
\text { enhanced }\end{array}$ & 2.70 & 1.40 & 14 & Medium \\
\hline 7 & $\begin{array}{l}\text { The employee awareness toward possible risks was } \\
\text { evaluated and tested }\end{array}$ & 2.91 & 1.35 & 13 & Medium \\
\hline 8 & Risk assessment survey was conducted & 3.33 & 0.99 & 11 & Medium \\
\hline 9 & $\begin{array}{l}\text { The word classifications for risks were used for risk } \\
\text { consequences and likelihood description }\end{array}$ & 4.05 & 1.01 & 5 & High \\
\hline 10 & Likelihood analysis was conducted & 4.15 & 1.55 & 3 & High \\
\hline 11 & Consequences analysis was conduced & 4.10 & 1.20 & 4 & High \\
\hline 12 & Risk allocation analysis was performed & 4.30 & 1.70 & 1 & High \\
\hline 13 & Alternatives for risk mitigation were investigated & 3.97 & 1.05 & 7 & High \\
\hline 14 & $\begin{array}{c}\text { All the involved parties of the project participated in } \\
\text { the risk analysis processes }\end{array}$ & 3.40 & 0.98 & 10 & Medium \\
\hline \multicolumn{2}{|r|}{ Risk analysis aspects as a whole } & 3.71 & 1.26 & - & High \\
\hline
\end{tabular}

The results of Table (3) below shows that the project performance within the large construction projects in Kuwait came in a high level with a mean of (4.03) and a standard deviation of (1.06). The item "The construction operations were carried out with minimum financing costs" came first with a mean of (4.35) and a standard deviation of (1.13) in a high level. On the other hand, the item "The project cost efficiency" came last with a mean of (3.80) and a standard deviation of (0.95) in a high level. 
Article no. 58

CIVIL

ENGINEERING

JOURNAL

THE CIVIL ENGINEERING JOURNAL 3-2021

Tab. 3: Study sample answers for the items of the indicators of the construction project performance

\begin{tabular}{|c|c|c|c|c|c|}
\hline No. & Item & Mean & SD & Rank & Level \\
\hline 1 & The project cost efficiency & 3.80 & 0.95 & 8 & High \\
\hline 2 & The project schedule efficiency & 3.81 & 1.00 & 7 & High \\
\hline 3 & $\begin{array}{c}\text { The construction operations were carried out with } \\
\text { minimum financing costs }\end{array}$ & 4.35 & 1.13 & 1 & High \\
\hline 4 & The project was profitable to date & 4.10 & 1.30 & 3 & High \\
\hline 5 & $\begin{array}{l}\text { The site activities were safely carried out with minimal } \\
\text { time incidents }\end{array}$ & 4.20 & 1.02 & 2 & High \\
\hline 6 & The project was delivered with a high quality & 4.00 & 1.09 & 5 & High \\
\hline 7 & Team satisfaction & 3.95 & 1.10 & 6 & High \\
\hline 8 & Client satisfaction & 4.05 & 0.90 & 4 & High \\
\hline \multicolumn{2}{|r|}{ Project performance indicators as a whole } & 4.03 & 1.06 & - & High \\
\hline
\end{tabular}

In order to find if there is an effect of the risk analysis on the performance of the construction project, Pearson correlation coefficient was calculated as in Table (4) below. It can be seen that there is a statistically significant relationship between the risk analysis aspects and the indicators of the construction project performance.

Tab. 4: the correlation coefficient between the risk analysis aspects and the indicators of the construction project performance

\begin{tabular}{|c|c|c|c|}
\hline Variable & Mean & $\begin{array}{c}\text { correlation } \\
\text { coefficient }\end{array}$ & $\begin{array}{c}\text { Statistical } \\
\text { significance }\end{array}$ \\
\cline { 1 - 2 } Risk analysis & 3.71 & \multirow{2}{*}{0.843} & $0.000^{\star}$ \\
\hline Construction project performance & 4.03 & & \\
\hline
\end{tabular}

* indicates statistically significant value

Such relationship was approved by the related literature, as in table (5) below that lists the results of examining the relationship between risk analysis and the construction project performance in three of the developing countries. 
Article no. 58

CIVIL

ENGINEERING

JOURNAL

THE CIVIL ENGINEERING JOURNAL 3-2021

Tab. 5: Examples on examining the relationship between risk analysis and construction project performance in the developing countries

\begin{tabular}{|c|c|c|c|}
\hline Study & Country & Setting & Results \\
\hline$[21]$ & Kenya & $\begin{array}{c}\text { Road } \\
\text { construction } \\
\text { project }\end{array}$ & $\begin{array}{c}\text { Risk analysis affect risk management } \\
\text { practices and performance. }\end{array}$ \\
\hline [22] & Egypt & $\begin{array}{c}\text { Roadways } \\
\text { construction } \\
\text { projects }\end{array}$ & $\begin{array}{c}\text { Risk analysis affects the execution of } \\
\text { the road construction project including } \\
\text { influencing the project objectives, time } \\
\text { and quality. }\end{array}$ \\
\hline$[23]$ & Kenya & $\begin{array}{c}\text { Construction } \\
\text { projects }\end{array}$ & $\begin{array}{c}\text { The finding showed that there was } \\
\text { positive relationship between } \\
\text { Quantitative Risk Analysis and Risk } \\
\text { Response, which led to the conclusion } \\
\text { that quantitative risk analysis and Risk } \\
\text { Response had a significance influence } \\
\text { on performance of construction } \\
\text { Projects. }\end{array}$ \\
\hline$[18]$ & Albania & $\begin{array}{c}\text { Construction } \\
\text { projects }\end{array}$ & $\begin{array}{c}\text { risk analysis has an impact on the } \\
\text { construction projects performance } \\
\text { related to time, quality and cost }\end{array}$ \\
\hline
\end{tabular}

In order to find if there are statistically significant differences in the sample answers attributed to the working setting, t-test was conducted, as in Table (6).

Tab. 6: $t$-test results for testing the differences between the sample answers attributed to the working setting variable

\begin{tabular}{|c|c|c|c|c|c|}
\hline \multicolumn{2}{|c|}{ Variable } & Mean & SD & t-value & $\begin{array}{c}\text { Statistical } \\
\text { significance }\end{array}$ \\
\hline \multirow{2}{*}{ Working setting } & Public sector & 3.2 & 0.92 & & \multirow{2}{*}{$0.00^{*}$} \\
\cline { 2 - 4 } & Private sector & 4.0 & 0.88 & 1.20 & 0.006 \\
\hline
\end{tabular}

* indicates statistically significant value

Finally, When the projects managers were asked about the main risk analysis tools that are common in large construction project in Kuwait, the tools included Risk matrix, Expert judgment, Value Analysis, Expected Monetary, FMEA, Fuzzy logic assessment, AHP and Monte Carlo simulation.

The projects managers also argued that the main effects of using the appropriate risk analysis tools on the performance of large construction projects in Kuwait include client satisfaction; maintaining the main resources, align with the budget, workers satisfaction, less conflict of interests among others.

Finally, the projects managers focused on the importance of communication, re-allocating risks and changing roles to reduce the risks within the large construction projects in Kuwait. 


\section{CONCLUSION}

Construction projects have different associated risks and this can be attributed to the multiple involved parties in the project, the required funds, technical and legal restrictions among others. The presence of risks in projects was proved to have a significant influence on the construction project performance. In this study, the risk analysis aspects effect on the construction project performance was investigated. The results showed that risk analysis do have an effect on the performance of construction projects, which is consistent with the related literature [24-28].

This study involved many limitations; the first was the study sample where more multidisciplinary sample is recommended to get a more comprehensive view of the problem since risk analysis is a mutual responsibility. The other limitation is that the results of this study cannot be generalized on the other countries and contexts; therefore, a comparative study should be conducted.

\section{RECOMMENDATIONS}

With the considerable effect of risk analysis has proved to have on the construction project performance, its associated operations should be established under both proactive and reactive ways. The effects of risk analysis should be also investigated from the perspective of project success or failure especially in the Middle East countries as most of the investigated studies in this subject were on developed economies. Risk analysis should be conducted using reliable validated methods in order to attain more reliable and practical results. With the gap found in this relationship in the public sector, more attention should be given to the risk analysis operations and the assessment methods within public large construction projects in Kuwait.

Priorities should be defined for each of the performance indicators in order to focus the risk analysis operations toward enhancing the performance. On the other hand, risk analysis operations should be directed toward sustainable risk management solutions in order to work on reducing risks with construction projects. Constant and continuous quality assurance is one of the major strategies that could be followed to decrease risks within construction projects with one integrated comprehensive platform that combine all the applications of risk analysis and management. Moreover, working systematically and taking care of documents can be a great of help to mitigate risks that could be reported earlier. Such systematic work argues that need also for good and solid communication between the project members and parties.

Risks can be reduced also by proper identification of risks and prioritize them to deal with them as they needed and by training the workers and all the parties of the construction project on how to deal with risks. Finally, there must be a guideline or standards that determine the risks and success of the construction projects in Kuwait.

\section{REFERENCES}

[1] N. Banaitiene and A. Banaitis, "Risk management in construction projects," Risk ManagementCurrent Issues and Challenges. In N. Banaitiene (Ed.), Risk Management-Current Issues and Challenges, pp. 429-448, 2012.

[2] K. Chatterjee, E. K. Zavadskas, J. Tamošaitienè, K. Adhikary, and S. Kar, "A hybrid MCDM technique for risk management in construction projects," Symmetry, vol. 10, no. 2, p. 46, 2018.

[3] M. Loosemore, J. Raftery, C. Reilly, and D. Higgon, "Risk and Uncertainty in Projects," ed: New York, NY, USA: Taylor and Francis, 2006.

[4] S. K. Viswanathan, K. K. Tripathi, and K. N. Jha, "Influence of risk mitigation measures on international construction project success criteria-a survey of Indian experiences," Construction Management and Economics, vol. 38, no. 3, pp. 207-222, 2020.

[5] M. Gunduz and A. M. A. Yahya, "Analysis of project success factors in construction industry," Technological and Economic Development of Economy, vol. 24, no. 1, pp. 67-80-67-80, 2018.

[6] S. M. El-Sayegh and M. H. Mansour, "Risk assessment and allocation in highway construction projects in the UAE," Journal of Management in Engineering, vol. 31, no. 6, p. 04015004, 2015. 
[7] S. M. El-Sayegh, S. Manjikian, A. Ibrahim, A. Abouelyousr, and R. Jabbour, "Risk identification and assessment in sustainable construction projects in the UAE," International Journal of Construction Management, pp. 1-10, 2018.

[8] S. Tan and K. Moinuddin, "Systematic review of human and organizational risks for probabilistic risk analysis in high-rise buildings," Reliability Engineering \& System Safety, vol. 188, pp. 233-250, 2019.

[9] C. Feng and S. Lu, "Using BIM to automate scaffolding planning for risk analysis at construction sites," in ISARC. Proceedings of the International Symposium on Automation and Robotics in Construction, 2017, vol. 34: IAARC Publications.

[10] A. KarimiAzari, N. Mousavi, S. F. Mousavi, and S. Hosseini, "Risk assessment model selection in construction industry," Expert Systems with Applications, vol. 38, no. 8, pp. 9105-9111, 2011.

[11] K. G. Lovejoy, P. I. Cross, and P. S. Tippett, "Object-oriented method, system and medium for risk management by creating inter-dependency between objects, criteria and metrics," ed: Google Patents, 2010.

[12] O. Zwikael, R. D. Pathak, G. Singh, and S. Ahmed, "The moderating effect of risk on the relationship between planning and success," International Journal of Project Management, vol. 32, no. 3, pp. 435-441, 2014.

[13] M. Urbański, A. U. Haque, and I. Oino, "The moderating role of risk management in project planning and project success: evidence from construction businesses of Pakistan and the UK," Engineering Management in Production and Services, vol. 11, no. 1, pp. 23-35, 2019.

[14] J.-S. Chou, N. Irawan, and A.-D. Pham, "Project management knowledge of construction professionals: Cross-country study of effects on project success," Journal of construction engineering and management, vol. 139, no. 11, p. 04013015, 2013.

[15] D. Baloi and A. D. Price, "Modelling global risk factors affecting construction cost performance," International journal of project management, vol. 21, no. 4, pp. 261-269, 2003.

[16] R. Takim and A. Akintoye, "Performance indicators for successful construction project performance," in 18th Annual ARCOM Conference, 2002, vol. 2, no. 4.

[17] H. Kerzner, Project management: a systems approach to planning, scheduling, and controlling. John Wiley \& Sons, 2017.

[18] A. Musta, "Impact of risk analysis related to time, quality and cost in construction projects," 2019.

[19] N. K. Nassar, "An integrated framework for evaluation of performance of construction projects," in $P M I 尺$ Global Congress, 2009, pp. 10-13.

[20] A. Dziadosz and M. Rejment, "Risk analysis in construction project-chosen methods," Procedia Engineering, vol. 122, pp. 258-265, 2015.

[21] O. Gregory, M. Yusuf, and K. Asinza, "Effect of Risk Identification and Risk Analysis on Performance of Road Construction Projects in Kenya: A Case Study of Kakamega County."

[22] U. H. Issa, K. G. Marouf, and H. Faheem, "Analysis of risk factors affecting the main execution activities of roadways construction projects," Journal of King Saud University-Engineering Sciences, 2021.

[23] J. M. Nzioki and M. N. Mwenda, "Promoting Performance of the Building Construction Industry through Risk Identification: A Case of Exchequer Funded Building Construction Projects in Machakos County, Kenya," 2020.

[24] E. Kinyua, K. Ogollah, and D. K. Mburu, "Effect of risk management strategies on project performance of small and medium information communication technology enterprises in Nairobi, Kenya," International Journal of Economics, Commerce and Management, vol. 3, no. 2, pp. 1-30, 2015.

[25] S. Nidumolu, "The effect of coordination and uncertainty on software project performance: residual performance risk as an intervening variable," Information systems research, vol. 6, no. 3, pp. 191-219, 1995. [26] M. M. d. Carvalho and R. Rabechini Junior, "Impact of risk management on project performance: the importance of soft skills," International Journal of Production Research, vol. 53, no. 2, pp. 321-340, 2015.

[27] R. Rabechini Junior and M. Monteiro de Carvalho, "Understanding the impact of project risk management on project performance: An empirical study," Journal of technology management \& innovation, vol. 8, pp. 6-6, 2013.

[28] L. Jun, W. Qiuzhen, and M. Qingguo, "The effects of project uncertainty and risk management on IS development project performance: A vendor perspective," International Journal of Project Management, vol. 29, no. 7, pp. 923-933, 2011. 


\section{APPENDIX A: THE QUESTIONNAIRE}

\section{EFFECT OF RISK ANALYSIS ON PERFORMANCE OF LARGE CONSTRUCTION PROJECTS IN KUWAIT}

\section{SOCIODEMOGRAPHIC INFORMATION}

1. Gender

$$
\text { Male }
$$

Female

2. Experience

$$
\begin{aligned}
& \text { Less than } 5 \text { years } \\
& 5 \text { to } 10 \text { years } \\
& \text { More than } 10 \text { years }
\end{aligned}
$$

3. Educational level

$$
\begin{aligned}
& \text { Bachelor } \\
& \text { Masters } \\
& \text { PhD }
\end{aligned}
$$

\begin{tabular}{|c|c|c|c|c|c|c|}
\hline No. & Item & 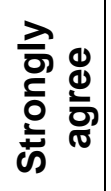 & ষ্ঠ & $\frac{\bar{\pi}}{\stackrel{\pi}{2}}$ & $\begin{array}{l}0 \\
\frac{0}{5} \\
\frac{.0}{0}\end{array}$ & 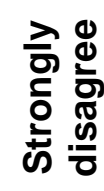 \\
\hline \multicolumn{7}{|c|}{ Risk Analysis Aspects } \\
\hline 1 & $\begin{array}{l}\text { Computer simulations and software } \\
\text { were used }\end{array}$ & & & & & \\
\hline 2 & $\begin{array}{l}\text { The financial impacts of the different } \\
\text { risks were identified and compared }\end{array}$ & & & & & \\
\hline 3 & $\begin{array}{l}\text { The organizational impacts of the } \\
\text { different risks were identified and } \\
\text { compared }\end{array}$ & & & & & \\
\hline 4 & $\begin{array}{l}\text { The gaps in the current safety } \\
\text { procedures were identified }\end{array}$ & & & & & \\
\hline 5 & The decision-making processes were & & & & & \\
\hline
\end{tabular}

4. Working setting

$$
\begin{aligned}
& \text { Public sector } \\
& \text { Private sector }
\end{aligned}
$$

5. Job title

$$
\begin{aligned}
& \text { Project Manager } \\
& \text { Assistant Project Manager } \\
& \text { Civil Engineer } \\
& \text { Building Inspector } \\
& \text { Surveyor } \\
& \text { Field Engineer } \\
& \text { Construction Engineer } \\
& \text { Planner }
\end{aligned}
$$


Article no. 58

CIVIL

ENGINEERING

JOURNAL

THE CIVIL ENGINEERING JOURNAL 3-2021

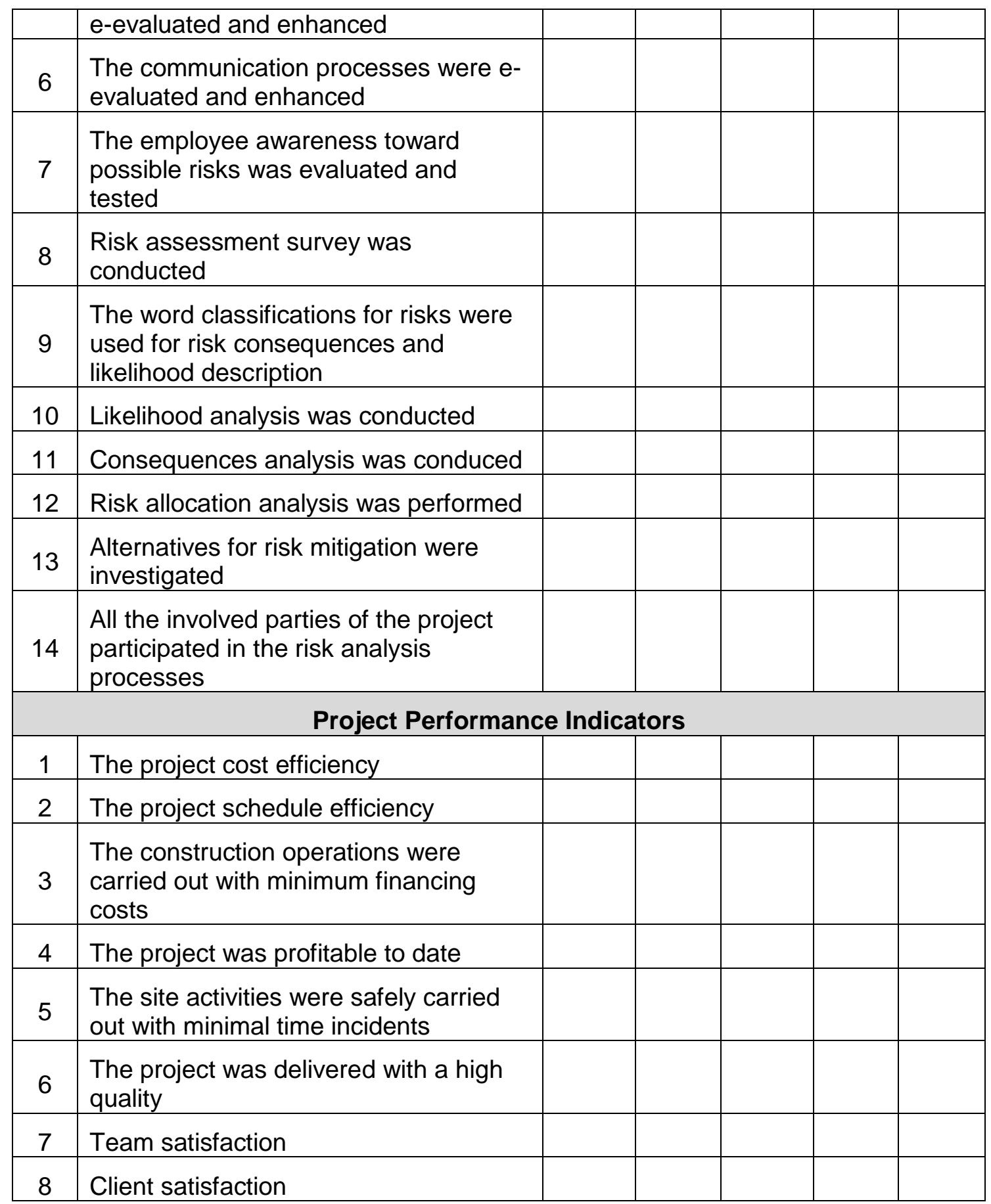

\section{APPENDIX B: THE INTERVIEW}

1. Based on your experience as a project manager for a large construction project in Kuwait, can you mention the main risk analysis tools that are common in such projects?

2. On your opinion, what are the main effects of using the appropriate risk analysis tools on the performance of large construction projects in Kuwait?

3. What are the main steps or strategies that can be followed to reinforce risk analysis practices in large construction projects in Kuwait? 